\title{
EVALUATION OF HIV-AIDS PREVENTION PROGRAM IN HOMOSEXUAL MEN IN JAMBI
}

\author{
Hubaybah, Adelina Fitri \\ Faculty of Medicine and Health Sciences, Universitas Jambi
}

\begin{abstract}
Background: Human Immunodeficiency Virus (HIV) infection remains a global public health concern. According to data in 2018, 37.9 million people in the world are infected with HIV. In Indonesia, the three most risky populations of HIV infection were injecting drug users (56\%), homosexual men (18\%), heterosexual (17\%), and the others (9\%), from April to June 2019. The reported data from the Integrated Biological and Behavioral Survey (IBBS) in 2015 showed that the significantly increased number of 2.5 times in the prevalence of HIV infection among homosexual men compared to the data from 2013. This study aimed to investigate the evaluation of HIV-AIDS prevention program in homosexual men in Jambi.

Subjects and Method: This was a qualitative study conducted at Kanti Sehati Sejati Foundation, Jelutung, Jambi, from April to July 2020. The study informants were head of the foundation, head of population outreach program, field accessor of the population outreach program, and assisted homosexual client. The data were collected by in-depth interviews and document reviews. The data were analyzed by reduction, displaying, and drawing conclusions/ verification.

Results: The input of the HIV-AIDS prevention was systematically programmed, including education on the used of lubricants and protection/ condoms, budget monitoring and evaluation, and counseling to homosexual men. The process of program had been implemented in accordance with the existing program implementation guidelines. The inhibiting factor of the program was the stigma of homosexual men families not supporting to seek health services. The output of the HIV-AIDS prevention program showed that homosexual men had improved the awareness of not changing partners, using condoms while having sex, and finding new cases of HIV.

Conclusion: HIV-AIDS prevention programs have been well implemented based on input, process, and output system approach. Peer group support is needed to persuade understanding of families from homosexual men to overcome the inhibiting factor of the program implementation.
\end{abstract}

Keywords: HIV-AIDS, prevention program, homosexual men

\section{Correspondence:}

Hubaybah. Faculty of Medicine and Health Sciences, Universitas Jambi. Jl. Letjend Soeprapto No 33 Telanai Pura Jambi. Email: hubaybah@unja.ac.id. Mobile: +628117453224 . 